九州大学学術情報リポジトリ

Kyushu University Institutional Repository

\title{
Several Genes Expression on Fructification of Lentinula edoes
}

Lee, Sang-Sun

Department of Biology, Korea National University of Education

Ohga, Shoji

Laboratory of Forest Resources Management, Division of Forest Ecosphere Management, Department of Forest and Forest Products Sciences, Kyushu University

https://doi.org/10.5109/24421

出版情報 : 九州大学大学院農学研究院紀要. 46 (1)，pp.47-59，2001-10-30. Kyushu University バージョン：

権利関係 : 


\title{
Several Genes Expression on Fructification of Lentinula edodes
}

\author{
Sang-Sun LEE* and Shoji OHGA** \\ Laboratory of Forest Resources Management, Division of Forest Ecosphere Management, \\ Department of Forest and Forest Products Science, Kyushu University, Kasuya, \\ Fukuoka 811-2415, Japan \\ (Received June 28, 2001 and accepted July 11, 2001)
}

\begin{abstract}
Lentimula edodes was cultivated in the artificial blocks of sawdust, and the fruiting body was induced on the surface of the sawdust blocks. The four different fungal stages; mycelia (D), primordia (C), stipes (B), and pileus (A) of fruiting bodies were collected for the extraction of mRNA, searching the genes related to morphogenesis. The three fragments of cDNA not showed in the stage (A) were picked up and displayed, to be two bands in the agarose gels. Total five bands were selected for analyzing the DNA sequences, using the pRIP-T ${ }^{\mathrm{TM}}$ vector system. The fragments of cDNA investigated in this work were not those related to the structural genes (exons), but to be related to the controlling genes (introns).
\end{abstract}

\section{INTRODUCTION}

The mushroom of Lentinula edodes (Berk.) Pegler (shiitake) is a wood rotting edible fungus belonging to the family of Tricholomataceae, and the most popular cultivated mushroom in the world (Chang and Miles, 1991). The traditional cultivation of L. edodes mainly uses natural logs, but its production depends on the climatic events, and a whole cycle of productions is very long for approximately five years. As the cultivation of other mushroom, the sawdust blended with the rice bran is developed for a new technique. After sterilization, each bags of substrate mentioned above is inoculated with the spawn and cultivated for 3-4 months (Diehle and Royse, 1991; Ohga et al., 1992; Lee et al., 2000). The mycelia of $L$. edodes form a compact mat on the sawdust solid substrate. In the presence of environmental induction (stress) such as temperature, humidity and light, which would often stress the mycelia, induce the hyphae to form primordium, which may subsequently develop into the fruiting bodies.

Understanding the control of fruit body initiation and maturation would be critical for the cultivation of $L$. edodes (Leung et al., 2000 Ohga et al., 2000b;). Studies on $L$. edodes have been focused mainly on the sawdust medium under the artificial cultivation (Kim et al., 1987; Ohga et al., 1992), the physiology and improvement of substrate (Park et al., 1992; Ohga et al., 2000b), selective breeding (Bak et al., 1996), the cultivation in liquid media (Song et al., 1987). Recently, molecular biological techniques have been applied to the study of $L$. edodes or other mushrooms, including with classification of isolate (Chiu et al., 1996; Lee et al., 1997; Park et al., 1997; Lee et al., 1999; Ohga et al., 1999; Ohga et al., 2000a) and isolations of the differentially expressed genes (Zhang et al., 1998; Leung et al., 2000). Molecular studies of $L$. edodes have been focused on

\footnotetext{
* Department of Biology, Korea National University of Education, Chungbuk 360-791, Korea

** Corresponding author, ohgasfor@mbox.nc.kyushu-u.ac.jp
} 
identifying the genes involved in the regulation of fruit body development (Lee et al., 1996; Ng et al., 2000). The gene is known to express only in primordium and immature fruiting bodies. The novel priA gene is actively transcribed at the state of primordia/immature fruiting bodies in L. edodes (Kajiwara et al., 1992). The novel priBc transcript is reported to be abundant in primordia, while pre-primordial mycelia and mature fruiting bodies contained lower levels of this gene transcript (Endo et al., 1994). The expression of $\beta$ subunit of mitochondrial processing peptidase ( $\beta$-MPP) gene is higher during the development of the fruiting bodies, suggesting that higher mitochondrial activities may be required to meet the energy demand in the rapid growth of the fruiting bodies (Zhang et al., 1998). Transcript level of Le hyd 1 is high in the primordium (Ng et al., 2000). In other L. edodes, developmental genes are expressed specifically in the fruit body; The $m f b A c$ transcript is abundant in mature fruiting bodies, detectable in immature fruiting bodies but absent in earlier developmental stages and in the vegetative mycelium (Kondoh et al., 1995; Ng et al., 2000).

The purposes of this study were subjected i) to identify, and ii) determine the differentially expressed genes in total RNA populations from three morphogenesis stages of L. edodes including mycelia, primordia and fruiting body, two tissues of stipe and pileus using the differential display reverse transcription-polymerase chain reaction (DDRT-PCR) (Liang and Pardee, 1992; Haag and Raman, 1994). Several genes differently expressed were detected and analyzed for further works.

\section{MATERIALS AND METHODS}

\section{Organism and culture}

A line of $L$. edodes (ImHyup-1; very commonly produced in the oak logs in Korea) was obtained from National Forestry Cooperatives Federation (NFCF) in Korea used for this purpose. The cultures of $L$. edodes were maintained on PDA (Potato Dextrose; Difco) at $25^{\circ} \mathrm{C}$. The blocks of PDA grown by $L$. edodes were cultured in synthetic liquid medium (glucose $20 \mathrm{~g}$, yeast extracts $2 \mathrm{~g}$, tryptone $2 \mathrm{~g}, \mathrm{KH}_{2} \mathrm{PO}_{4} 1 \mathrm{~g}, \mathrm{MgSO}_{4} 0.75 \mathrm{~g}, \mathrm{FeSO}_{4}$ $0.02 \mathrm{~g}, \mathrm{ZnSO}_{4} 0.02 \mathrm{~g}, \mathrm{H}_{2} \mathrm{O} 1 \mathrm{~L}$ ) at $25^{\circ} \mathrm{C}$ by shaking incubator for the liquid spawn. The mycelia cultured in the liquid broth were inoculated to the $1-1.5 \mathrm{~kg}$ of the sterilized oak sawdust (with rice bran by the ratio $80: 20$ ) moistured by the approximately $60 \%$ before sterilization. The L. edodes was grown on sawdust substrate at $25^{\circ} \mathrm{C}$ in the dark rooms for three months until the white mycelia was covered in whole surface. To induce fruiting, the substrate blocks were kept in moist and cool room (at $15^{\circ} \mathrm{C}$, for 2 days) under the dim light (Lee et al., 2000). Four stages of mycelial growth were collected for this work; (A): Pileus of fruiting body, (B): Stipe of fruiting body, (C): Primordium from the surface of the sawdust, and (D): Mycelia colonized in the sawdust media shown in Fig. 1.

\section{RNA isolation}

The total RNA's from the fungal tissues mentioned above were extracted by the based SDS-Phenol extraction method (Ausbel et al., 1999); all samples (5g of the fungal tissue and $15 \mathrm{~g}$ of the mycelia mixed with the sawdust) were ground in liquid nitrogen using mortars and pestles. The grounded tissues were transferred into the $50 \mathrm{M} \ell$ centrifuge tube, and the extraction buffer (0.18 $\mathrm{M}$ tris, $\mathrm{pH} 8.7,90 \mathrm{mM} \mathrm{LiCl}, 4.5 \mathrm{mM}$ EDTA, 1\% SDS) 
were added to the tube. An equal volume of acidic phenol $(\mathrm{pH} 4.3)$ were added to and mixed into the homogenized powder. After centrifugation at $12,000 \mathrm{rpm}$ at $4^{\circ} \mathrm{C}$ for $10 \mathrm{~min}$, the $5 \mathrm{M} \ell$ of the top phase was transferred to a new $50 \mathrm{M} \ell$ centrifuge tube and was added with an equal volume of chloroform. The mixture was shaken vigorously and was centrifuged at $12,000 \mathrm{rpm}$ at $4^{\circ} \mathrm{C}$ for $10 \mathrm{~min}$. The $800 \mu l$ of the top phase was, again, transferred to a new eppendorf tube (E-tube) and an equal volume of $4 \mathrm{M} \mathrm{LiCl}$ was added to. The tube was placed overnight at $-20^{\circ} \mathrm{C}$ to precipitate RNA, and centrifuged at $12,000 \mathrm{rpm}$ at $4^{\circ} \mathrm{C}$ for $10 \mathrm{~min}$. The supernatant was decanted and the pellet was rinsed with the $2 \mathrm{M} \mathrm{LiCl}$ solution and the tube was centrifuged, again. The pellet was washed with the $70 \%$ ethanol and dried, dissolved in $50 \mu \ell$ DEPC-treated water. The RNA sample was treated with the RNA PrepMateTM Lysis buffer and an equal volume of chloroform was added to, again. The same procedure was duplicated with the isopropanol and $70 \%$ ethanol, as described, until the pure RNA sample was obtained. The pellet was dissolved in the $100 \mu \ell$ DEPC-treated water, and was measured by spectrophotometer for RNA concentration. Finally, the bands of RNA's were confirmed by the electrophoresis method, using the formaldehyde agarose gel (Ausbel et al., 1999; Sambrook et al., 1989).

\section{DDRT-PCR}

The CDNA corresponding to the RNA's extracted was synthesized from by a reverse transcriptase reaction by using the AccuPowerTM RT PreMix (Bioneer). Each $20 \mu \ell$ mixture contained $1 \mu \mathrm{g}$ of total RNA, 1,2,3 M-MLV reverse transcriptase $20 \mathrm{U}$, RNasin $10 \mathrm{U}$, stablizer, tracking dye and $20 \mathrm{pmol} 3$ ' one anchored oligo-dT primers (Table 1 ). The reverse transcription was performed at $42^{\circ} \mathrm{C}$ for $1 \mathrm{~h}$ and the reaction was stopped by incubation at $94^{\circ} \mathrm{C}$ for $5 \mathrm{~min}$. The cDNA synthesized was stored at $-20^{\circ} \mathrm{C}$ for a subsequent PCR reaction. One tenth of the CDNA was then amplified in a total volume of the $20 \mu \ell$ the PCR mixtures contained $1 \mathrm{U}$ Taq DNA polymerase, the $250 \mu \mathrm{M}$ dNTP of each, $10 \mathrm{mM}$ Tris- $\mathrm{HCl}$ ( $\mathrm{pH} 9.0$ ) $, 40 \mathrm{mM} \mathrm{KCl}, 1.5 \mathrm{mM} \mathrm{MgCl}_{2}$, stabilizer, tracking dye (Bioneer), $20 \mathrm{pmol} 3$ ' one anchored oligo-dT primers and $20 \mathrm{pmol}$ arbitrary primers. The amplification reaction was done for $1 \mathrm{cycle}$ with $94^{\circ} \mathrm{C}$ for $5 \mathrm{~min}, 40^{\circ} \mathrm{C}$ for $30 \mathrm{sec}, 72^{\circ} \mathrm{C}$ for $30 \mathrm{sec}$; $30 \mathrm{cycles}$ with $94^{\circ} \mathrm{C}$ for $30 \mathrm{sec}, 40^{\circ} \mathrm{C}$ for $30 \mathrm{sec}, 72^{\circ} \mathrm{C}$ for $1 \mathrm{~min}$, and an additional extension cycle with $94^{\circ} \mathrm{C}$ for $30 \mathrm{sec}, 40^{\circ} \mathrm{C}$ for $30 \mathrm{sec}, 72^{\circ} \mathrm{C}$ for $5 \mathrm{~min}$. The $5 \mu \ell$ of the PCR products were resolved on a $1.5 \%$ agarose gel and stained with ethidium bromide for confirmation. The band was photographed with Digital Camera (Kodak).

Table 1. Primers used in the experiment.

\begin{tabular}{|c|c|c|}
\hline Primer & Length & Nucletide sequences \\
\hline oligo $\mathrm{dT} / \mathrm{G}$ & 16 mer & 5' - AAGCTTTTTTTTTTTG - 3' \\
\hline oligo $\mathrm{dT} / \mathrm{C}$ & 16 mer & 5 - AAGCTTTTTTTTTTTC - 3' \\
\hline oligo dT/A & 16 mer & 5 - AAGCTTTTTTTTTTTA - 3' \\
\hline $\mathrm{AP} 1$ & 13 mer & $5-$ AAGCTTGATTGCC - 3' \\
\hline $\mathrm{AP} 2$ & 13 mer & $5^{\prime}-$ AAGCTTCGACTGT - 3 \\
\hline AP 3 & 13 mer & $5^{\prime}-\underline{\text { AAGCTTTGGTCAG - }} 3^{\prime}$ \\
\hline $\mathrm{AP} 4$ & 13 mer & 5 - AAGCTTCTCAACG - 3' \\
\hline
\end{tabular}




\section{Electrophoresis}

Electrophoresis was performed on the Econo Sequencer I ${ }^{\mathrm{TM}}$ Electrophoresis System (Bioneer). The $6 \mu \ell$ of loading dye was added to $15 \mu \ell$ of each DDRT-PCR products and the mixtures were heated for $5 \mathrm{~min}$ at $100^{\circ} \mathrm{C}$; the $3 \mu \ell$ mixture was loaded on the sequencing gel. The sequencing gel was prepared, and pre-run at $1600 \mathrm{~V}$ until the xylen cyanol dye was reached the bottom of the gel. The gel was stained by silver staining method using a Silverstar ${ }^{\mathrm{TM}}$ staining kit (Bioneer) by followed with the supplier's specifications. After electrophoresis, the plate was separated using the plastic wedge. The gel (plate) was placed in a shallow plastic tray, covered with fix/stop solution (10\% glacial acetic acid) and agitated for $30 \mathrm{~min}$. The gel was rinsed three times ( $2 \mathrm{~min}$ each) with the ultra pure water using agitation. The gel was transferred to staining solution $(0.1 \%$ $\mathrm{AgNO}_{3}, 0.15 \%$ formaldehyde) and agitated well for $30 \mathrm{~min}$. The gel was also briefly dipped into the tray containing the ultra pure water. The solution in the tray was drained, and placed immediately into the tray of chilled developing solution. The gel was agitated well until the template band starts to be developed or until the first bands was visible and continued developing for an additional $2-3 \mathrm{~min}$. To terminate the developing reaction and fix the gel, the fix/stop solution was directly added to the developing solution and incu-bated with shaking for 2-3 min. The gel was rinsed twice for $2 \mathrm{~min}$ with the ultra pure water and placed on the dried at the room temperature. The PCR-amplified cDNA products were resolved on a $6 \%$ poly-acrylamide sequencing gel.

\section{cDNA fragment}

The bands representing the cDNA differentially expressed were excised with a scalpel blade. The cDNA fragments were soaked in $100 \mu \ell$ of distilled $\mathrm{H}_{2} \mathrm{O}\left(\mathrm{dH}_{2} \mathrm{O}\right)$ for $10 \mathrm{~min}$, boiled for $15 \mathrm{~min}$ and centrifuged for $2 \mathrm{~min}$, and clarified by precipitation (Reeves et al., 1994). The cDNA precipitated were diluted with the buffer in the rate of $1 / 20$. For $\mathrm{PCR}$ reactions, the $2 \mu \ell$ dilution cDNA products were used in $20 \mu \ell$ PCR mixtures contained $1 \mathrm{U}$ Taq DNA polymerase, each $250 \mu \mathrm{M}$ dNTP, $10 \mathrm{mM}$ tris- $\mathrm{HCl}(\mathrm{pH} 9.0), 40 \mathrm{mM}$ $\mathrm{KCl}, 1.5 \mathrm{mM} \mathrm{MgCl}_{2}$, stabilizer, tracking dye (Bioneer). Using the same set of ' 3 ' one anchored oligo-dT primers in combinations with the arbitrary primer (AP). The amplification was made for 1 cycle with $94^{\circ} \mathrm{C}$ for $5 \mathrm{~min}, 40^{\circ} \mathrm{C}$ for $30 \mathrm{sec}$, and $72^{\circ} \mathrm{C}$ for $30 \mathrm{sec} ; 30 \mathrm{cycle}$ with $94^{\circ} \mathrm{C}$ for $30 \mathrm{sec}, 40^{\circ} \mathrm{C}$ for $30 \mathrm{sec}, 72^{\circ} \mathrm{C}$ for $1 \mathrm{~min}$ and an additional extension cycle with $94^{\circ} \mathrm{C}$ for $30 \mathrm{sec}, 40^{\circ} \mathrm{C}$ for $30 \mathrm{sec}, 72^{\circ} \mathrm{C}$ for $5 \mathrm{~min}$. The re-amplified cDNA fragments were resolved on a $1.5 \%$ agarose gel and stained with ethidium bromide. The bands were photographed with Digital Camera (Kodak) and estimated their sizes with the standard markers.

\section{DNA sequencing}

The re-amplified cDNA were cloned into the pRIP-T ${ }^{\mathrm{TM}}$ vector system and transformed in to $E$. coli $\mathrm{DH} 12 \mathrm{~S}$ (Bioneer). DNA sequencing was performed by the dideoxy sequencing method (Ausbel et al., 1998). The date for the cDNA sequence were edited and used to searching the homology BLAST X (URL: http://www.ncbi.nlm.nih.gov; Altschul et al., 1990). The sequence of DNA fractions was confirmed with the modified Northern hybridization using unfractionated RNA immobilized by the slot blotting (Sambrook et al., 1989) 


\section{RESULTS}

\section{Growth}

The ImHyup-1 line of $L$. edodes, were selected from more than 20 lines known and being commercially sold in Korea. This line was developed for cultivation of $L$. edodes, a long time ago, because the rapid growth takes place in the log cultivation and morphogenesis at the high temperate as compared with other lines of L. edodes. Also, this line was known to be traditionally cultivated in the oak or other tree logs. The liquid spawns grown were inoculated in the sawdust solid blocks and the cultivation was made at $25^{\circ} \mathrm{C}$ under a laboratory ways. The white mycelia grew for 1 or 1.5 months in the dark room and covered the whole surface of sawdust blocks (D in Fig. 1). To induce fruiting body (primordium), the sawdust substrate was kept in the moist and cool room under dim light. The white mycelia turned to the black brown color (C in Fig. 1) and made to produce several harden mass in the surfaces. This mass was projected out for a week in the cooled room, showing B in Fig. '1. Finally, more than ten basidiocarps were protruded from the mass on the surfaces of the black brown block (A in Fig. 1).
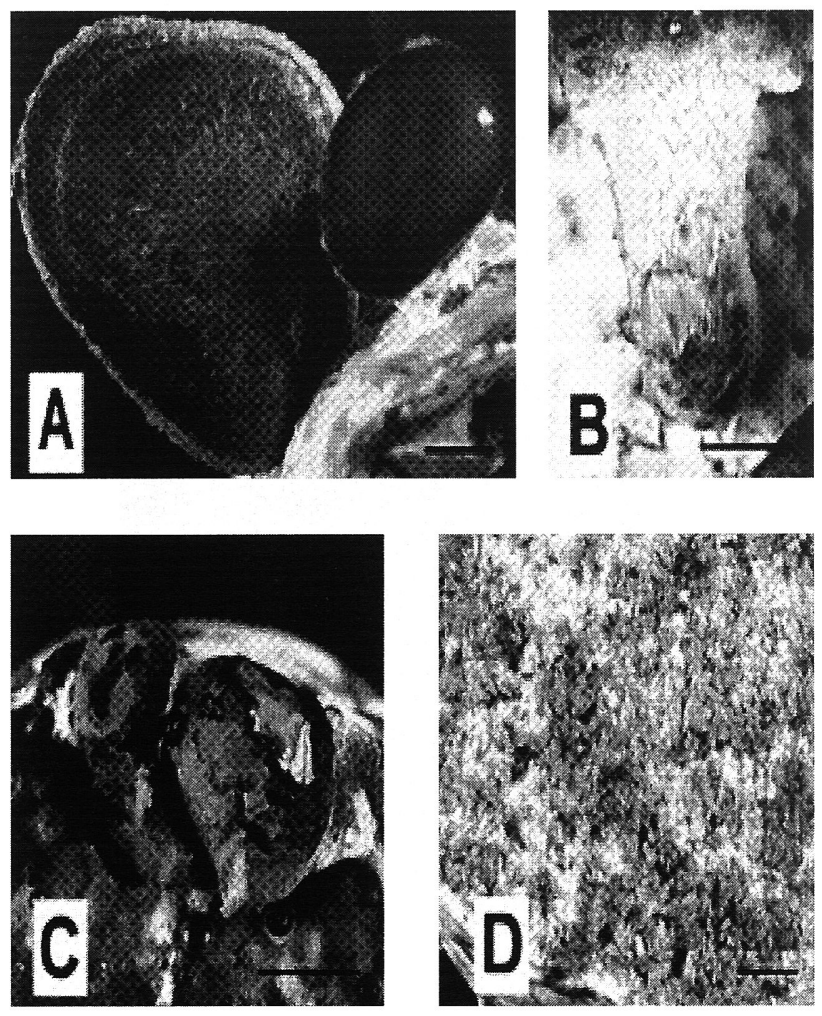

Fig. 1. The different stages of $L$. edodes growth; A: Formation of fruiting body pileus, B: Fruiting body stipe, C: Primordia formations from the surface of the sawdust, D: Mycelia colonized in the sawdust media (Scale bars $=1 \mathrm{~cm}$ ). 


\section{RNA bands}

The DDRT-PCR was displayed after reacted with the equal amounts of RNA (1 $\mu \mathrm{g})$ extracted from each of the three developmental stages and different tissue types using three 3' one anchored oligo-dT primer combinations with the four arbitrary primers (Figs. 2 and 3). To distinguish the different genes expressed, the detail bands of the DDRT-PCR products shown in Figs. 2 and 3 were run on the 1.5\% agarose gel and stained with ethidium bromide (Fig. 4). Several times, these products were displayed on the agarose gel, but the bands were difficultly distinguished as compared with those shown in the $6.0 \%$ polyacrylamide gels (Figs. 2 and 3 ). The four differential display fragments ( $\mathrm{F}$ series; the bands marked in the left of Fig. 2) were distinguished, when the primer of AP \# 1 was reacted with the three different anchored oligo-dT primers; The fine bands of the fragments indicated above were also displayed on the $6.0 \%$ polyacrylamide gels shown in both Figs. 2 and 3. The band or fragment of $\mathrm{F}-1$ originated from the tissues of primordi-

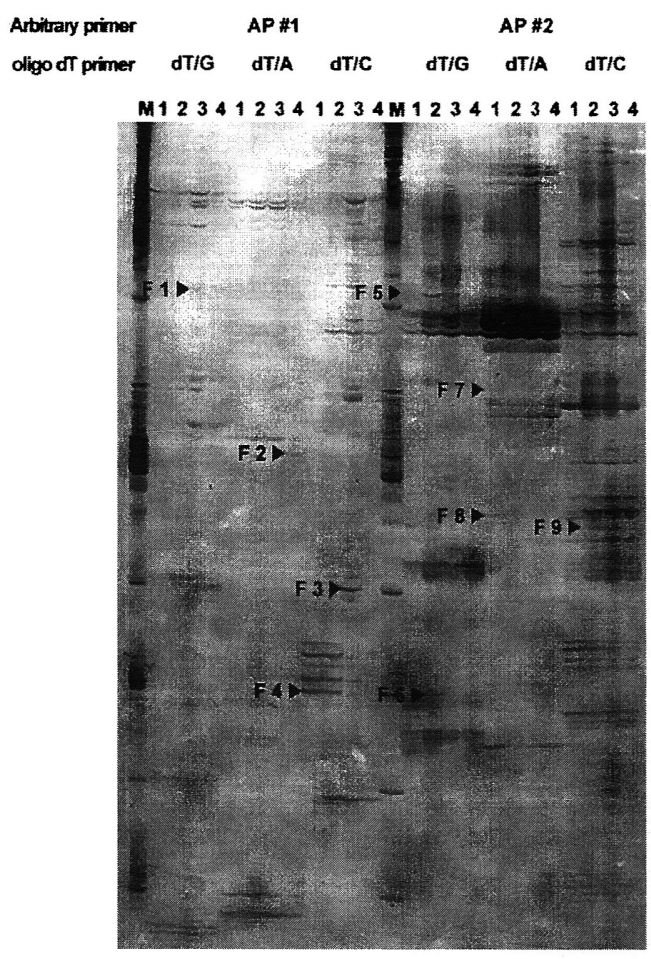

Fig. 2. Differential display of total RNA from the three development stages and different tissue types of $L$. edodes using the arbitrary primers AP \# 1 and AP \# 2. The DDR-PCR bands were displayed on $6 \%$ polyacrylamide gel stained with the silver staining method. Marked (M): marker (100 bp ladder), 1: Fruiting body pileus, 2: Fruiting body stipe, 3: Primordia, 4: Mycelia. 


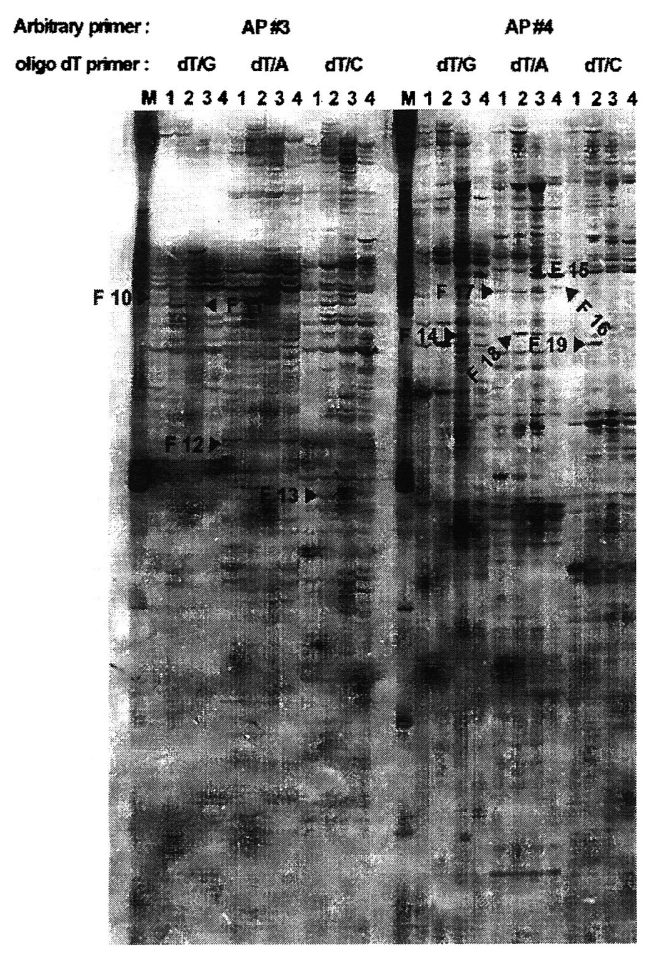

Fig. 3. Differential display of total RNA from the three development stages and different tissue types of $L$. edodes using the arbitrary primers AP \# 3 and AP \# 4. The DDRT-PCR products were resolved on $6 \%$ polyacrylamide gel stained with silver staining method. Marked M: the marker (100 bp ladder), 1: Fruiting body pileus, 2: Fruiting body stipe, 3: Primordia, 4: Mycelia.

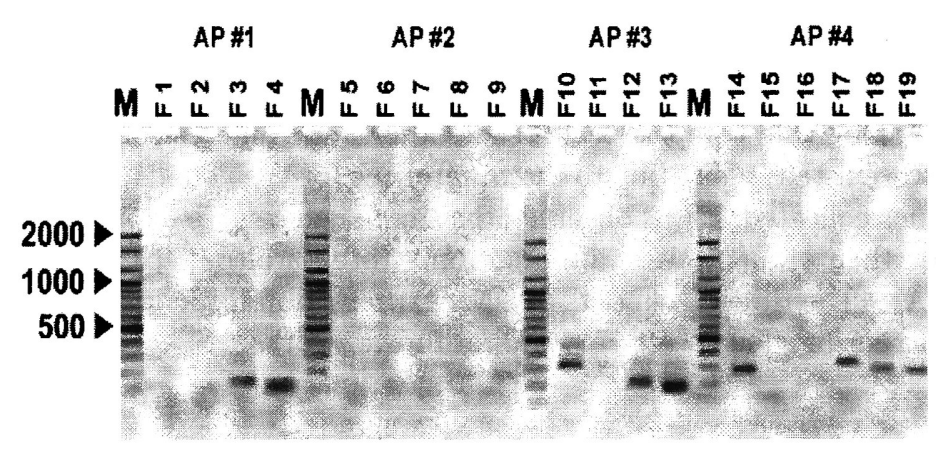

Fig. 4. The reamplified bandproducts differentially expressed by $L$. edodes on $1.5 \%$ agarose gel. The differentially expressed bands were picked up from the polyacrylamide gel. Marked M: marker (100 bp ladder). 
Table 2. The fragments of gene differentially expressed and determinated.

\begin{tabular}{|c|c|c|c|c|c|c|c|}
\hline \multirow[b]{2}{*}{ Fragments } & \multicolumn{2}{|c|}{ Primer combination } & \multirow{2}{*}{$\begin{array}{c}\text { Molecular } \\
\text { weight }^{\mathrm{a}} \\
\text { (bp) }\end{array}$} & \multicolumn{4}{|c|}{ Expression stage and tissue } \\
\hline & $\begin{array}{c}\text { Arbitrary } \\
\text { primer }\end{array}$ & $\begin{array}{c}\text { Oligo-dT } \\
\text { primer }\end{array}$ & & Pileus & Stipe & Primordia & Mycelia \\
\hline F 1 & $\mathrm{AP} 1$ & $\mathrm{dT} / \mathrm{G}$ & $-{ }^{\mathrm{b}}$ & & & 0 & 0 \\
\hline F 2 & $\mathrm{AP} 1$ & $\mathrm{dT} / \mathrm{A}$ & - & & & & 0 \\
\hline F 3 & AP 1 & $\mathrm{dT} / \mathrm{C}$ & 150 & & & 0 & \\
\hline F 4 & $\mathrm{AP} 1$ & $\mathrm{dT} / \mathrm{C}$ & 110 & 0 & 0 & & \\
\hline F 5 & $\mathrm{AP} 2$ & $\mathrm{dT} / \mathrm{G}$ & - & $\bigcirc$ & 0 & 0 & \\
\hline F 6 & $\mathrm{AP} 2$ & $\mathrm{dT} / \mathrm{G}$ & - & & 0 & & \\
\hline F 7 & $\mathrm{AP} 2$ & $\mathrm{dT} / \mathrm{A}$ & - & 0 & & & \\
\hline F 8 & $\mathrm{AP} 2$ & $\mathrm{dT} / \mathrm{A}$ & - & 0 & 0 & & \\
\hline F 9 & $\mathrm{AP} 2$ & $\mathrm{dT} / \mathrm{C}$ & 160 & 0 & 0 & 0 & \\
\hline F 10 & $\mathrm{AP} 3$ & $\mathrm{dT} / \mathrm{G}$ & 320 & 0 & 0 & 0 & \\
\hline F 11 & AP 3 & $\mathrm{dT} / \mathrm{G}$ & - & 0 & 0 & 0 & \\
\hline F 12 & AP 3 & $\mathrm{dT} / \mathrm{A}$ & 240 & 0 & 0 & & \\
\hline F 13 & AP 3 & $\mathrm{dT} / \mathrm{C}$ & 230 & & 0 & & \\
\hline F 14 & $\mathrm{AP} 4$ & $\mathrm{dT} / \mathrm{G}$ & 300 & & & 0 & 0 \\
\hline F 15 & $\mathrm{AP} 4$ & $\mathrm{dT} / \mathrm{A}$ & - & 0 & 0 & & \\
\hline F 16 & $\mathrm{AP} 4$ & $\mathrm{dT} / \mathrm{A}$ & 160 & & & & 0 \\
\hline F 17 & $\mathrm{AP} 4$ & $\mathrm{dT} / \mathrm{A}$ & 330 & 0 & 0 & 0 & \\
\hline F 18 & $\mathrm{AP} 4$ & $\mathrm{dT} / \mathrm{A}$ & 300 & & 0 & 0 & 0 \\
\hline F 19 & $\mathrm{AP} 4$ & $\mathrm{dT} / \mathrm{C}$ & 300 & & 0 & & \\
\hline
\end{tabular}

a) Re--amplified molecular weight

b) Re-amplification band was not shown.

um and mycelia were distinguished from those originated from the others. The fragment of F-2 was expressed on only the tissue of mycelium, when the mRNA was reacted with the primer of $\mathrm{AP} \# 1$ and the anchored oligo-dT/A primers. The fragment of $F-5, F-9$ to 11 , or $\mathrm{F}-17$ was found in the fungal tissues of pileus, stipe, and primordium, but not in the fungal tissues of mycelia. Many fragments of $\mathrm{F}$-series were displayed on the mRNA originated from the fungal tissues of stipe, as compared with those reactions originated from the other tissues. The two fragments of $\mathrm{F}-14$ and $\mathrm{F}-18$ were selected with $\mathrm{F}-3$ for further works. The bands or fragments synthesized and displayed, after many reactions of mRNA with the three arbitrary primers with three 3' one anchored oligo-dT primers, were listed in Table 2 and compared with each other. The nineteen fragments marked in Figs. 2 and 3 were listed, again, due to the differences for the genetic genes expressed to the fungal tissues collected; It was observed that more genes were expressed in the fungal tissues of stipe than other tissues, although only three arbitrary primers were reacted with the mRNA's. The three fragments of DNA expressed in three fungal tissues, but not in the fungal tissues of pileus, were selected for further works.

\section{Sequence}

The nineteen fragments of DDRT-PCR were selected, reacted with the two different primers mentioned above, and confirmed with the re-amplification on the $1.5 \%$ agarose gels (Fig. 4). Several fragments were showed to be stained with the darken bands in the 
Table 3. The DNA sequences of the bands obtained from DDRT-PCR.

\begin{tabular}{|c|c|c|}
\hline \multirow[b]{2}{*}{ Clones } & \multicolumn{2}{|c|}{ Sequences } \\
\hline & $\begin{array}{l}\text { Length } \\
\text { (bps) }\end{array}$ & The sequences determined \\
\hline F 3-1 & 140 & $\begin{array}{l}\text { Aagcttgattgccaatgtgaggaagggtttcctggcaattgtattaatccaggagtaagtcg } \\
\text { atcttaaaaccagtcctaaagggtcaataaggccatatattattaaatttatatattcctgatg } \\
\text { gttgaaaaaaaaaa }\end{array}$ \\
\hline F 3-2 & 121 & $\begin{array}{l}\text { Aagctttttttttttcaaccatcaggaatatataaatttaataatatatttccttattgacccttt } \\
\text { aggactggttttaagatcgacctactcctggattaatacaattgccaggaaaccc }\end{array}$ \\
\hline F 14-1 & 143 & $\begin{array}{l}\text { Aagcttttttttttggcatacatcaggagtaatttattgacaagtagtgtccaaatttggataaa } \\
\text { tatggtcaagcaatatttatgcattaagtatacggttagcatatgtgettgaaacaagagaaat } \\
\text { agctctcatcaacc }\end{array}$ \\
\hline F 14-2 & 165 & $\begin{array}{l}\text { Aaagaagctatggatgaaggggaattcgatgaagatgagcatgacgaatatgactatgacg } \\
\text { acgacgacgatgagcggtgtccggaggtggacacaaggttgatgagagctatttctcttgtt } \\
\text { tccaacacatattctaaccgtatacttaaatgcataaatatt }\end{array}$ \\
\hline F 18 & 199 & $\begin{array}{l}\text { Gaattcactagtgattaagettctcaacgtgctgcctcagetttcgttatccttacaggaact } \\
\text { ctcctatacacttatgtcaaatctcgggagagtggeccatccaaccctcatcaggaaccaa } \\
\text { ttctgcacctttgaaggatttggaatctcagtctacaaaacaggaacaggtggatgaaaagc } \\
\text { cgctcacttaag }\end{array}$ \\
\hline
\end{tabular}

The poly A tails underlined. The black box represented $3^{\prime}$ UTR region. Direction $5^{\prime} \rightarrow 3^{\prime}$.

staining dyes. Out of the nineteen fragments, only three fragments made from the DDRT-PCR fingerprints (F-3, F-14 and F-18) were selected for determining the DNA sequences. The re-amplified cDNAs of the fragments sized about 110 to $330 \mathrm{bps}$ in the length of DNA were shown to be a single band or double band, except that some were not showed nor clearly (Fig. 4). The two fragments (darken and dim bands) of F-3 and F-14 were shown and obtained for the DNA sequences. The fragment of F-18 was also selected for this further work. The five fragments were cloned to the pRIP-T ${ }^{\mathrm{TM}}$ vector known and determined for the DNA sequences. The fragments picked up from the polyacrylamide gels (Figs. 2 and 3) were loaded in the agarose gel, again, and showed to be separated to two kinds of band shown in Fig. 4. The two bands shown in the fragments of F-3 and F-14 (Fig. 4) were also picked up, being determined by the DNA sequences. The DNA sequences were determined under a range of $200 \mathrm{bps}$ and showed in Table 3. The two fragments of $\mathrm{F}-3$ were determined to be a DNA sequences of $\mathrm{A} / \mathrm{T}$ rich $140 \mathrm{bps}$, whereas the fragments of $\mathrm{F}-18$ of $\mathrm{C} / \mathrm{T}$ rich sequence with $190 \mathrm{bps}$. The nucleotides of $\mathrm{A}$, $\mathrm{T}, \mathrm{C}$, and $\mathrm{G}$ were observed be evenly distributed in the fragment of $\mathrm{F}-18$ rather than the others. The F-3 clone was identified by hybridization to the 18sRNA of primordium (Fig. 5). The five DNA sequences were searched for further information by BLAST search program. However, the 15 to $20 \mathrm{bps}$, the partial region, of fragment were completely matched with those of several genes showed in Table 4, indicating the control gene (the 'intron' gene called in searching the Blast $\mathrm{X}$ ). The partial region of DNA sequence 


\section{Pileus Stipe Primordium Mycelia}

F-3

18s RNA

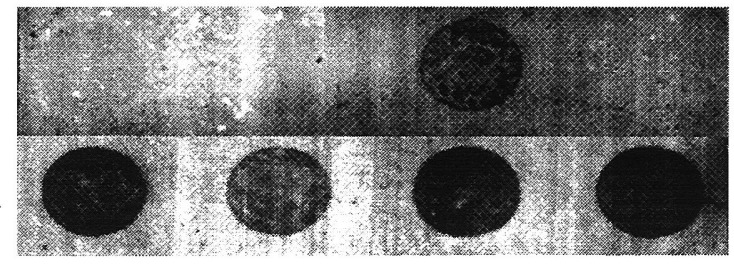

Fig. 5. Dot blotting of the unfractionated RNA of fragment-3 immobilized by the slot blotting.

Table 4. The DNA sequences of the five fragments compared with the other genomic sequences obtained from the the BLAST searchings.

\begin{tabular}{|c|c|c|c|}
\hline & Code number & $\begin{array}{l}\text { The organisms and some } \\
\text { descriptions }\end{array}$ & Homology sequences \\
\hline F3-1 & $\begin{array}{l}\text { gb|U69572.1|CPU6957 } \\
\text { gb|U41277.11CELCOC6EE4 } \\
\text { gblAE003442.11AE003442 } \\
\text { gblAC004845.2|AC004845 } \\
\text { gb|AC004749.11AC004749 }\end{array}$ & $\begin{array}{l}\text { Mitochondrion Culex pipiens A+T rich m } \\
\text { Caenorhabditis elegans cosmid C06E4 } \\
\text { Drosophila melanogaster genomic scaf } \\
\text { Homo sapiens clone RP4-63505, comple } \\
\text { Homo sapiens chromosome } 5, \text { P1 clone }\end{array}$ & $\begin{array}{l}97 \rightarrow 119: 636 \text { atatattattaaatttatatatt } 658 \\
99 \rightarrow 119: 15414 \text { atattattaaatttatatatt } 15394 \\
97 \rightarrow 116: 167763 \text { atatattattaaatttatat } 167782 \\
97 \rightarrow 120: 50459 \text { atatattatttaatttatatattc } 5048 \\
96 \rightarrow 115: 36497 \text { catatattattaaatttata } 36478\end{array}$ \\
\hline F 3-2 & $\begin{array}{l}\text { gblU69572.11CPU69572 } \\
\text { refiNC_001993.1 } \\
\text { gblAF063866.1IAF063866 } \\
\text { gb|U41277.1ICELC06E4 } \\
\text { gblAE003442.11AE003442 }\end{array}$ & $\begin{array}{l}\text { Mitochondrion Culex pipiens A+T } \\
\text { I Melanoplus sanguinipes } \\
\text { entomopoxvirus } \\
\text { Melanoplus sanguinipes entomopoxviru } \\
\text { Caenorhabditis elegans cosmid C06E4 } \\
\text { Drosophila melanogaster genomic scaf }\end{array}$ & $\begin{array}{l}27 \rightarrow 49: 658 \text { aatatataaatttaataatatat } 636 \\
27 \rightarrow 51: 24133 \text { aatatataaagttaataatatattt } 24109 \\
27 \rightarrow 51: 24133 \text { aatatataaagttaataatatattt } 24109 \\
27 \rightarrow 47: 15394 \text { aatatataaatttaataatat } 15414 \\
30 \rightarrow 49: 167782 \text { atataaatttaataatatat } 167763\end{array}$ \\
\hline F 14-1 & $\begin{array}{l}1 \text { gb|AE003528.1|AE00319528 } \\
\text { gb|AC006075.1|AC006075 } \\
\text { gb|U73649.1IU73649 } \\
\text { gb|U61947.1ICELC06G3 } \\
\text { gb|AC012446.2|AC012446 }\end{array}$ & $\begin{array}{l}\text { Drosophila melanogaster genomic } \\
\text { Homo sapiens chromosome } 16 \\
\text { Human Chromosome } 11 \text { Cosmid } \\
\text { Caenorhabditis elegans cosmid } \\
\text { Homo sapiens clone RP11-101A12 }\end{array}$ & $\begin{array}{l}75 \rightarrow 95: 281829 \text { gcaatatttatgcattaagta } 281849 \\
108 \rightarrow 128: 155819 \text { atgtgcttgaaacaagagaaa } 155799 \\
103 \rightarrow 123: 21689 \text { agcatatgtgcttgaaacaag } 21669 \\
25 \rightarrow 43: 1920 \text { aggagtaatttattgacaa } 1938 \\
64 \rightarrow 85: 71654 \text { aatatggtcaagcagtatttat } 71633\end{array}$ \\
\hline & $\begin{array}{l}\text { gb|J05161.1LUMHBC } \\
\text { emb|AJ249549.1IEMU249549 } \\
\text { reflNC_001139.1 } \\
\text { emb|Z72749.1ISCYGL227W } \\
\text { dbj|AB025323.1IAB025323 }\end{array}$ & $\begin{array}{l}\text { Earthworm (L.terrestris) extracellular } \\
\text { Echinococcus multilocularis } \\
\text { Saccharomyces cerevisiae chromosome } \\
\text { VII } \\
\text { S. cerevisiae chromosome VII } \\
\text { Eptatretus burgeri mRNA }\end{array}$ & $\begin{array}{l}50 \rightarrow 74: 1111 \text { atgactatgacgacgacgacgatga } 1135 \\
12 \rightarrow 39: 2295 \text { ggatgaaggggaattcgatgaggatgag } 23 \\
50 \rightarrow 74: 70202 \text { atgacgatgacgacgacgacgatga } 70226\end{array}$ \\
\hline F 18 & $\begin{array}{l}\text { emblAL365234.11ATT'30N20 } \\
\text { emblAL121776. IHSJ1050K3 } \\
\text { gb|AC009541.16|AC009541 } \\
\text { gb|AC002352.11AC002352 } \\
\text { gb|AC005255.11AC005255 }\end{array}$ & $\begin{array}{l}\text { Arabidopsis thaliana DNA chromosome } \\
\text { Human DNA sequence } \\
\text { Human Chromosome } 7 \text { clone } \\
\text { Homo sapiens 12q24 PAC P256D10 } \\
\text { Homo sapiens chromosome } 19\end{array}$ & $\begin{array}{l}68 \rightarrow 87: 16388 \text { tatacacttatgtcaaatct } 16407 \\
170 \rightarrow 189: 74436 \text { aacaggtggatgaaaagccg } 74455 \\
147 \rightarrow 165: 80344 \text { ggaatctcagtctacaaaa } 80362 \\
129 \rightarrow 147: 6002 \text { tgcacctttgaaggatttg } 6020 \\
138 \rightarrow 160: 92056 \text { gaaggatttggaatcacagtcta } 92034\end{array}$ \\
\hline
\end{tabular}

The fragments synthesized were compared with the genes informed from the GeneBank 
matched above was searched to originate from the eucaryotic cells but not from the prokaryotic cells. The fragments selected from this work, especially A+T rich DNA sequence in F3-1 and F3-2, were considered to be a control gene (intron), but not a structural genes (exon; see the literatures of gblU69572.1/CPU69572 Mitochondrion Culex pipiens A+T rich or gblU41277.1 ICELC06E4 Caenorhabditis elegans). Some regions of the fragment $\mathrm{F}-18$ was also searched to be matched with the intron genes (repeating regions) and the structural genes (exon) of DNA sequences.

\section{DISCUSSION}

The line of ImHyeop-1 L. edodes were known to be the fungus grown rapidly in the high temperature. The liquid spawn was employed for rapid growth in the common sawdust blocks. The morphognesis were induced under several known conditions. The mycelia was inoculated by the liquid spawn and cultured in the sawdust blocks for 1 or 1.5 month (Fig. 1). After then, the mycelia were observed to turn to dark brown color and, after then, to several protruding mass ( 2 or $3 \mathrm{~cm}$ diameters) in the surfaces (C in Fig. 1). Morphogenesis of $L$. edodes was observed to take place under certain conditions, although it was concerned under the conditions of our laboratory. The mRNA's induced by the four different stages of $L$. edodes morphogenesis were collected, reacted with the arbitrary primers and synthesized to the genes of cDNA's. The genes related to morphogenesis would be considered to be very important for commercial production of $L$. edodes in Eastern Asia. Thus, the genes inducing the morphogenesis of basidiocarp were considered to be critical for the production of commercial mushroom in the agricultures.

Many genes were expressed in the DDRT-PCR, when the three arbitrary primers of AP 2, 3 and 4 were reacted with mRNA rather than the other arbitrary primer \# 1 . Particularly, the many genes were detected when the AP primers were reacted with the end primers of the oligo primers $\mathrm{T} / \mathrm{C}$; the many bands or fragments were observed on the electrophoresis gels when the arbitrary primers \# 2 or \# 4 reacted with the oligo primers T/C. This would be helpful, especially, for further work of $L$. edodes or its related species. The gene fragments not expressed in only a fungal tissue were observed in the preparations of stipe more than the others, so less expressed in the preparations of mycelia. (Table 2, and Figs. 2 and 3). Generally, so many genes expected to be expressed in the fungal tissues of basidiocarps (pileus and stipe), because more complexity of structure was found in the basidiocarps than in the mycelia of the fungus. The fragments $(\mathrm{F}-3, \mathrm{~F}-14$, and $\mathrm{F}-18)$ observed in preparations of the three fungal tissues, excluding the tissue of pileus, were selected for the analyses of DNA sequence. In other words, the possible genes related to the morphogenesis of basdiocarp should be expected to exist in the fungal tissues of mycelia, primordia and stipe (Table 2). The two fragments of $\mathrm{F}-3$ and $\mathrm{F}-14$ picked up from the agarose gels were showed to be two bands, again, and total five bands selected were determined to the DNA sequence shown in Table 3. The two fragments darken (F3-1: $140 \mathrm{bp}$ ) and the dim bands (F3-2: $121 \mathrm{bp}$ ) in Fig. 4, picked up from the one fragment (F-3 fragment in Fig. 2) were quite different each other's in the analysis of DNA sequences (Table 3 ).

Our works for the genes induced for morphogenesis were very important in the commercial production of $L$. edodes, even though the five fragments selected above 
should be confirmed by Northern blot or other PCR methods. All fragments analyzed by DNA sequence (Table 3) were searched to match with other DNA sequences of gene provided from Blast X. The analyses of the protein for the DNA sequences of the fragment selected were not conducted because finding the genes related to morphogenesis of basidiocarp were aimed by using the methology of DDRT-PCR. The minute differences between the fragments shown in the polyacryl-amide gels were tried to be detected for the mRNA originated from the different fungal tissues and also to be related to the DNA sequences. Our work was subjected to detect the differences of fragment shown in the polyacrylamide gels for the further work of $L$. edodes.

\section{ACKNOWLEDGEMENTS}

This work was financially supported by Korea Agricultural Research and Development Promotion Center ('99 Nongteuk Project). This work was also supported by a Grant-in-Aid for Scientific Research (No. (C) (2) 12660153) from the Ministry of Education, Science, Sports and Culture of Japan.

\section{REFERENCES}

Altschul, S. F., W. Gish, W. Miller, E. W. Myers and D. J. Lipman 1990 Basic local alignment search tool. J. Mol. Biol, 215: 404-410

Ausubel, F. M., R. Brent, R. E. Kingston, D. D. Moor, J. G. Seidman, J. A. Smith and K. Struhl 1999 Current protocols in molecular biology. USA.

Bak, W. C., T. S. Lee, B. H. Byun and C. K. Yi 1996 Selective breeding and hybridization of Lentinus edodes strains for bed-log cultivation. J. Korean For. Soc., 85: 309-315

Chang, S. T. and P. G. Miles 1991 Recent trends in world production of cultivated mushrooms. Mush. J., 503: $15-18$

Chiu, S. W., A. M. Ma, F. C. Lin and M. David 1996 Genetic homogeneity of cultivated strains of shiitake (Lentinula edodes) used in China as revealed by the polymerase chain reaction. Mycol. Res., 100: 1393-1399

Diehle, D. A. and D. J. Royse 1991 Effect of substrate heat treatment on biological efficiency (BE) and size of a selected line of Lentinus edodes. In "Science and Cultivation of Edible Fungi", ed. By M. J. Maher, Balkema, Roterdam, pp. 517-521

Endo, H., S. Kajiwara, S. Tsunoka and K. Shishido 1994 A novel cDNA, priBc, encoding a protein with a Zn (II) 2 Cys 6 zinc cluster DNA-Binding motif, derived from basidiomycete Lentinus edodes. Gene, 139: $117-121$

Haag, E. and V. Raman 1994 Effects of primer choice and source of Taq DNA polymerase on the banding patterns of Differential Display RT-PCR. Biotechnique., 17: 226-228

Kajiwara, S., K. Yamaoka, K. Hori, H. Miyazawa, T. Saito, T. Kanno and K. Shishido 1992 Isolation and sequence of a developmentally regulated putative novel gene, priA, from the basidiomycete Lentinus edodes. Gene, 114: 173-178

Kim, H. K., Y. H. Park, D. Y. Cha and H. C. Chung 1987 Studies on the artificial cultivation of Lentinus edodes on sawdust media. Kor. J. Mycol., 15: 42-47

Kociok, N., K. Unfried, P. Esser, R. Krott, U. Schraermeyer and K. Heimann 1998 The nonradioisostopic representation of differentially expressed mRNA by a combination of RNA fingerprinting and differential display. Mol. Biotechnol., 9: 25-33

Kondoh, S., A. Muto, S. Kajiwara, J. Takagi, Y. Saito and K. Shishido 1995 A fruting body-spcific cDNA, $m f b A c$, from the mushroom Lentinus edodes encodes a high-molecular-weight cell-adhension protein containing an Arg-Gly-Asp motif. Gene, 154: 31-37

Lee, S. S., S. W. Hong, H. C. Jung, C. K. Sung, J. H. Kim, K. H. Ka and H. J. Kim 1999 The specific probes confirming the genomic DNA of Tricholoma matsutake in Korea. Kor. J. Mycol., 27: 20-26 
Lee, T. S., H. D. Kang, W. C. Bak, C. K. Yi and D. S. Min 1996 Electrophoretic porfiles of proteins from the mycelia and fruiting-bodies of Lentinus edodes strains in Kroea. FRI. J. For. Sci., 54: 207-213

Lee, T. S., W. C. Bak, H. D. Kang, S. K. Kim, B. H. Byun, C. K. Yi, W. K. Lee and D. S. Min 1997 Classification of Korean Lentinula edodes strains by random amplified polymorphic DNA (RAPD) markers. Kor. J. Mycol., 25: 219-225

Lee, T. S., G. H. Yoon, W. C. Park, J. S. Kim and J. Y. Lee 2000 New cultivation techniques of oak-mushroom. For. Res. Rep. Korea For. Res. Inst.

Leung, G. S., M. Zhang, W. J. Xie and H. S. Kwan 2000 Identification by RNA fingerprinting of genes differentially expressed during the development of the basidiomycete Lentinula edodes. Mol. Gen. Genet., 262: 977-990

Liang, P. and A. B. Pardee 1992 Differential display of eukaryotic messenger RNA by means of the polymerase chain reaction. Science, 257: $967-971$

Ng, W. L., T. P. Ng and H. S. Kwan 2000 Cloning and characterization of two hydrophobin genes differentially expressed during fruit body development in Lentinula edodes. FEMS Microbiol. Lett., 185: $139-145$

Ohga, S., N. S. Cho, C. F. Thurston and D. A. Wood 2000a Transcriptional regulation of laccase and cellulase in relation to fruit body formation in the mycelium of Lentinula edodes on a sawdust-based substrate. Mycoscience, 41: 149-153

Ohga, S., D. S. Min, C. D. Koo, T. H. Choi, A. Leonowicz and N. S. Cho 2000b Culture maturity of Lentinula edodes on sawdust-based substrate in relation to fruiting potential. Mokchae Konghak, 28: $55-64$

Ohga, S., F. V. Roozendael, M. Aspinwall and M. Miwa 1992 Yield and size response of the shiitake, Lentinus edodes, depending on incubation time on sawdust-based culture. Trans. Mycol. Soc. Japan, 33: 349-357

Ohga, S., M. Smith, C. F. Thurston and D. A. Wood 1999 Transcriptional regulation of laccase and cellulase genes in the mycelium of Agaricus bisporus during fruit body development on a solid substrate. Mycol. Res, 103: 1557-1560

Park, W. M., C. H. Song and J. W. Hyun 1992 Nutritional physiology and improvement of substrate of Lentinus edodes. Kor. J. Mycol., 20: 77-82

Park, W. M., H. G. Ko, R. J. Park, K. S. Hong and G. H. Kim 1997 Differentiation of Lentinus edodes isolates in Korea by isozyme polymorphisms and random amplified polymorphic DNA (RAPD) analysis. Kor. J. Mycol., 25: 176-190

Reeves, S. A., M. Rubio and D. Louis 1994 General method for PCR ampification and direct sequencing of mRNA differential display product. BioTec., 19:18-20

Sambrook, J, E. F. Fritsch and T. Maniatis 1989 Molecular cloning: a laboratory manual, 2nd ed., Cold Spring Harbor Laboratory, Cold Spring Harbor, NY

Song, C. H., K. Y. Cho and N. G. Nair, N. G. 1987 A synthetic medium for the production of submerged cultures of Lentinus edodes. Mycologia, 79: 866-876

Zhang, M., W. Xie, G. S. Leung, E. E. Deane, and H. S. Kwan 1998 Cloning and characterization of the gene encoding beta subunit of mitochondrial processing peptidase from the basidiomycetes Lentinula edodes. Gene, 206: $23-27$ 